\title{
Sub-National Institutions, Firm Strategies, and Firm Performance: A Multilevel Study of Private Manufacturing Firms in Vietnam
}

\section{Authors: Thang V. Nguyen, Ngoc T. B. Le, and Scott E. Bryant}

NOTICE: this is the author's version of a work that was accepted for publication in Journal of World Business. Changes resulting from the publishing process, such as peer review, editing, corrections, structural formatting, and other quality control mechanisms may not be reflected in this document. Changes may have been made to this work since it was submitted for publication. A definitive version was subsequently published in Journal of World Business, VOL\# 48, ISSUE\# 1, (January 2013)] DOI\# 10.1016/j.jwb.2012.06.008

Nguyen, Thang V., Ngoc T.B. Le, and Scott E. Bryant. "Sub-National Institutions, Firm Strategies, and Firm Performance: A Multilevel Study of Private Manufacturing Firms in Vietnam." Journal of World Business 48, no. 1 (January 2013): 68-76. doi:10.1016/j.jwb.2012.06.008.

Made available through Montana State University's ScholarWorks scholarworks. montana.edu 


\title{
Sub-national institutions, firm strategies, and firm performance: A multilevel study of private manufacturing firms in Vietnam
}

\author{
Thang V. Nguyen ${ }^{a}$, Ngoc T.B. Le ${ }^{b}$, Scott E. Bryant ${ }^{\text {c,* }}$ \\ ${ }^{a}$ Asia Pacific Institute of Management, National Economics University, Hanoi, Viet Nam \\ ${ }^{\mathrm{b}}$ NEU Business School, National Economics University, Hanoi, Viet Nam

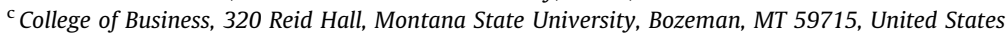

\begin{abstract}
A B S T R A C T
Some private small and medium sized enterprises (SMEs) in transition economies have actively internationalized. This decision needs to accommodate institutional conditions that vary, not only between countries, but also within an individual country. Our paper examines the relationship between export strategy and firm performance, and the extent that sub-national institutional factors moderate this relationship. Using multilevel data analysis techniques with a sample of private manufacturing firms in Vietnam, we find institutional factors moderate export strategy and firm performance's relationship. (c) 2012 Elsevier Inc. All rights reserved.
\end{abstract}

\section{Introduction}

The internationalization of private small and medium-sized enterprises (SMEs) in emerging economies has fostered growing research interest in these organizations (e.g., Buckley et al., 2007; Zhu, Hitt, \& Tihanyi, 2007). Compared to their counterparts in developed countries, SMEs in emerging markets face additional challenges coping with an institutional reality that is uncertain and biased in favor of larger firms (Hoskisson, Eden, Lau, \& Wright, 2000; Le, Venkatesh, \& Nguyen, 2006; Wright, Filatotchev, Hoskisson, \& Peng, 2005). While institutions' roles in SMEs' internationalization strategy and performance have been discussed conceptually in the literature (Luo \& Tung, 2007; Witt \& Lewin, 2007; Yamakawa, Peng, \& Deeds, 2008; Zhu et al., 2007), research has provided little empirical analysis. There is a need to specify the analysis process and explain the underlying mechanisms of these institutional influences on SMEs' performance and strategies (Peng, 2003). This is especially important when studying SMEs in emerging economies where institutions are overly complex and rapidly changing. Our paper addresses this research question: How do different aspects of market institutions in emerging economies influence SMEs' internationalization strategy and performance?

To separate institutions' impact from national culture and history's impact on firm strategies, we rely on the significant variation in institutional development within a country (Bertolini \& Giovannetti, 2006; Gao, Murray, Kotabe, \& Lu, 2010; Meyer \& Nguyen, 2005). Our paper examines the relationships between local institutions, firm export strategy, and firm performance using a sample of private manufacturing firms in 64 Vietnam provinces. We examine how a firm's export strategy is linked with its performance, and specify how this relationship is moderated by relevant local institutional factors. We use Hierarchical Linear Modeling (HLM) to explicitly model firm and institutional level residuals, recognizing the partial interdependence of firms within the same institutional group. This technique also allows us to model firm and institutional level variance in firm performance, while utilizing firm predictors at the firm level, and institutional predictors at the institutional level.

Vietnam is a particularly suitable context for this study because the country has gone through a major economic transition process. Weaknesses in its formal institutions remain major obstacles for business (Nguyen, 2005a; Tran, Grafton, \& Kompas, 2009). Recent studies in the country suggest that provincial institutions vary greatly (Meyer \& Nguyen, 2005; VNCI-VCCI, 2006). This makes it possible to examine how provincial institutions interact with a firm's export strategy to influence firm performance.

We review relevant literature on institutions and SMEs internationalization in emerging economies in the following section. We then develop hypotheses that link provincial institutional factors with firm performance, and specify how provincial institutions moderate the relationships between firm strategies and performance. Research methodology and findings follow. Our paper concludes with a discussion of theoretical and managerial implications. 


\section{Theoretical background}

\subsection{Institutions and SMEs internalization in emerging economies}

Research on SMEs' internationalization has grown significantly in the last decade (e.g., Oviatt \& McDougall, 1994). Several researchers have studied the internationalization of SMEs in emerging economies, suggesting there is convincing evidence that a number of SMEs have begun to internationalize and make their presence felt overseas. Compared to their counterparts in developed countries, SMEs in emerging economies face additional and tremendous challenges in coping with uncertain institutional environments from their home countries (Buckley et al., 2007; Le et al., 2006; Luo \& Tung, 2007; Witt \& Lewin, 2007; Yamakawa et al., 2008; Zhu et al., 2007). Therefore, accounting for institutional environments is critical to understanding how SMEs in emerging economies can expand into foreign markets. The influence of institutions on SMEs' internationalization can be categorized into "push" and "pull" factors.

\subsubsection{Push factors}

Emerging economies' institutional environments "push" SMEs to internationalize in several ways. Private SMEs often face unequal regulative environments and tend to suffer from higher costs in setting up and running their businesses (Yamakawa et al., 2008). The governments in many emerging economies are more interested in supporting larger firms, including those with domestic and foreign investment. In some cases, the government retains partial ownership in large firms (Buckley et al., 2007; Nguyen, Le, \& Freeman, 2006; Yamakawa et al., 2008). As a result, private SMEs may be starved of resources and short on market opportunities in their own countries. This is evident in several countries including China (Buckley et al., 2007), Indonesia (Wengel \& Rodriguez, 2006), countries in Eastern Europe (Smallbone \& Welter, 2001), and Vietnam (Nguyen, 2005b). Consequently, internationalization provides these SMEs an opportunity to avoid intense competition in their home markets.

In addition, private SMEs in emerging economies often face high barriers to gaining legitimacy because larger firms are dominant and recognized as legitimate (Le et al., 2006; Yamakawa et al., 2008; Zhu et al., 2007). In some transition economies, private SMEs may be at a disadvantage simply due to their privately owned status (Nguyen et al., 2006; Peng, 2001). In addition to the liability of newness and smallness, the general public may view these SMEs as companies that exploit workers, cheat the government, or provide low quality products (Nguyen, 2005a; Peng, 2001; Smallbone \& Welter, 2001).

Partnering with foreign companies or having products accepted in foreign markets may help these SMEs increase their legitimacy (Estrin, Meyer, Wright, \& Foliano, 2008; Yamakawa et al., 2008). As a response, some SMEs have found internationalization to be an effective means of participating in other national institutional contexts that are perceived to be in closer alignment with the firms' needs (Luo \& Tung, 2007; Meyer \& Boisot, 2008; Witt \& Lewin, 2007; Yamakawa et al., 2008; Zhu et al., 2007).

\subsubsection{Pull factors}

On the other hand, the reform of institutional environments in emerging economies can also provide "pull" factors for SMEs to internationalize. Critical pull factors include the improvement of government transparency, providing information, and government support for internationalization strategies. A government with consistent, liberal, and transparent economic policies facilitates the internationalization of SMEs in several ways. First, clear and transparent policies reduce the procedural cost of going international for SMEs. As reported in previous studies (e.g., Buckley et al.,
2007), private SMEs often encounter highly bureaucratic and burdensome administrative Foreign Direct Investment (FDI) approval procedures as government officials, at various levels, seek to influence the amount, direction, and scope of outward capital flows. If this is combined with discriminatory policy tools against certain industries and ownership forms, internationalization's costs can be very high. Second, facilitating information flow and making information on foreign markets and potential partners accessible is important for SMEs to develop successful international strategies (Eriksson, Johanson, Majkgard, \& Sharma, 1997; Julien \& Ramangalahy, 2003). This information and knowledge is critical for SMEs to identify and realize opportunities in foreign markets and develop competitive capabilities.

These institutions serve as a complex moderator of SMEs' internationalization strategies. On the one hand, the underdevelopment of institutions could serve as a push factor for SMEs to go international. On the other hand, any progress in making government policies transparent and information available would facilitate the internationalization of SMEs. It is reasonable to expect the effect of SMEs' internationalization strategies depends in part on specific national and sub-national institutions (Bertolini \& Giovannetti, 2006; Luo \& Tung, 2007; Yamakawa et al., 2008; Zhu et al., 2007).

\subsection{Export strategy and firm performance}

Export strategies are the simplest form and/or early stage of internationalization (Oviatt \& McDougall, 1994). For most SMEs in transition economies, exporting remains the most effective and accessible internationalization strategy. With a lack of resources and institutional support, exporting provides these firms with efficient access to foreign markets and an opportunity to gain valuable international experience (Lu \& Beamish, 2001). This is an especially valuable learning experience for firms in transition economies since their capability to compete internationally is quite limited. As a result, exporting pushes (and at the same time, helps) firms build their competitiveness.

Empirical results, however, have been inconclusive. Several studies of firms in transition economies have found that export intensity positively influenced firm performance (Gao et al., 2010; Luo, Zhou, \& Liu, 2005). Other research has suggested that exporting could be detrimental to those firms due to their disadvantage in developing resources and institutional linkages necessary to succeed in foreign countries and that the impact of export strategies on firm performance may be contingent on other factors, such as firm capability (Lyles, Saxton, \& Watson, 2004). Additional studies have suggested institutional environment may play a role (Bertolini \& Giovannetti, 2006; Luo \& Tung, 2007; Yamakawa et al., 2008; Zhu et al., 2007). We focus on the moderating effect of institutional factors on SME's export strategies and performance in subsequent sections.

\section{Hypothesis development: provincial institutions, firm export strategies, and performance}

\subsection{Institutional theory}

Institutional theory has been recognized as one of the most relevant perspectives for studying firm strategies in emerging economies (Hoskisson et al., 2000; Wright et al., 2005). In these countries, where formal institutions (i.e., the legal framework and enforcement of laws) are in their nascent stages, informal institutions (similar to the cognitive and normative dimensions) appear to be critical. These informal dimensions of institutions may vary within a country undergoing a process of change (Meyer \& Nguyen, 2005). While sub-national authorities may not have 


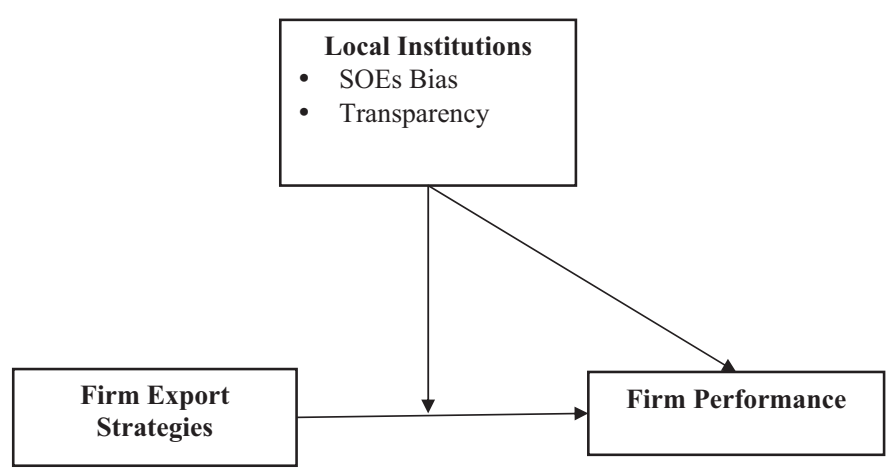

Fig. 1. Theoretical framework.

law-setting authority regarding private business, their knowledge of and attitude toward private business greatly influence how they interpret and implement the laws set by the central government. The changes in these institutions' informal dimensions are often slow and complex (North, 1990). This is highly relevant in the context of emerging economies (Peng, Wang, \& Jiang, 2008).

We discuss and develop hypotheses regarding two aspects of these provincial institutions: (1) bias toward state-owned firms (property rights issue); and (2) provincial transparency and information provision (reflects knowledge and information's role in economic development). Fig. 1 illustrates the theoretical framework of this paper.

\subsection{SOE bias}

A key element of institutions is how state-owned enterprises (SOEs) handle property rights issues (North, 1990). We focus on local governments' attitudes and policies toward the state and the domestic private sector as one indication of the institution's view of property rights. In many emerging economies, the government retains some ownership in large firms (e.g., China's Lenovo and Vietnam's Petrolimex). These large firms enjoy easy access to major resources, such as bank loans and land (Buckley et al., 2007; Nguyen, 2005a; Yamakawa et al., 2008; Zhu et al., 2007). In contrast, SMEs in these countries are often discriminated against in accessing these resources. For example, a study in Singapore (Ramirez \& Tan, 2004) tested the assertion that government-linked companies (GLCs) were encroaching into too many industries, enjoying unfair advantages in terms of access to funds, tenders, and opportunities, and effectively crowding out the private sector and hindering the development of a critical mass of thriving local enterprises. Their analysis found GLCs' share prices did enjoy a premium, indicating some favorable treatment.

In Vietnam, after more than two decades of reform, SOEs are still seen as playing a "leading role" in the economy. The economic reform and business liberalization process in Vietnam has been a delicate balancing act, between promoting the private sector on the one hand, and maintaining the leading role of the state enterprise sector on the other. This balancing act has been arguably a root cause of wide disparities in economic reforms implementation at the provincial level, with provincial governments adopting markedly different pro-SOE or pro-private sector development strategies.

Provinces that favor state ownership tend to emphasize SOEs' development, as indicated by their numbers, relative contribution to provincial gross domestic product (GDP), and various other indicators. According to this approach, SOEs should be large in number, be a major part of the provincial economy, and dictate the pace of provincial development. Private enterprises that survive and develop under the hegemony of SOEs are in some ways controlled by SOEs, and are largely dependent on SOEs. This results in SOEs getting more support, for example, more resources and better access to markets, than private firms (Meyer \& Nguyen, 2005; Nguyen, 2005b; Ramasamy, Yeung, \& Laforet, in press). SOEs' favored status make private firms less profitable. Favored status also mitigates the effectiveness of their resources because these private firms, even with resources available to invest, cannot enter more profitable areas. Officials often cite sociopolitical stability and socialist ideology as the main reasons for following this approach (Nguyen, 2005a).

On the other hand, there are provinces that are more progressive in promoting the private sector. In these provinces, SOEs could be fewer in number, and should give space for-and embrace-competition from the private sector. In other words, private firms are given sufficient access to resources to develop independently from SOEs, are encouraged to reach out beyond local markets, and to compete with their SOE peers. Private firms are not "satellites" of SOEs. Rather, they are equal partners and/or competitors with their SOE peers. Compared to private firms in more SOE-biased provinces, those in these provinces are more profitable. Their resources are also more effectively utilized since they are not constrained by what the SOEs do (Meyer \& Nguyen, 2005; Nguyen, 2005b). Therefore we hypothesize:

Hypothesis 1a. Provincial favorable treatment of SOEs negatively influences private firm performance.

SMEs in emerging economies may view internationalization as an escape from domestic discrimination and competition from SOEs. Favorable treatment of SOEs which blocks SMEs from accessing domestic resources and markets, serves as a push factor for these SMEs to look for foreign markets (Peng, 2001). When discriminated against in the domestic market, finding foreign markets would be critical for SME's survival and development. Foreign markets would serve as the base from which SMEs can reach targeted customers, compete more equally, and learn from the competition.

Yamakawa et al. (2008) cited Baidu, a privately owned Chinese Internet start-up firm, as an example. At home, Baidu was blatantly discriminated against by the Chinese securities authorities; it was not allowed to list its stock on China's stock exchange-only SOEs could apply. Essentially, Baidu was pushed out of China to list its stock in the U.S., which turned out to be successful (Yamakawa et al., 2008). Another study (Meyer \& Boisot, 2008) suggested that Chinese SMEs internationalize when the costs of crossing provincial borders exceed the costs of crossing national borders. This insight suggests that when local inefficient logistics and protectionism (including SOE bias) increase the costs of doing business domestically, SMEs may need to go to foreign markets. As documented in several other previous studies, highly favorable treatment of SOEs in home countries or provinces blocks SMEs from creating and penetrating domestic markets (Nguyen, 2005b; Ramirez \& Tan, 2004). In this situation, an export strategy may help SMEs escape from intense competition and serve a foreign market in which they may not be discriminated against.

In brief, the more limited the opportunities in domestic markets are, the more value an export strategy would contribute to firm performance. Therefore, we hypothesize:

Hypothesis 1b. The more favored treatment SOEs in the province receive, the more positive effect the private firm's export strategy will have on firm performance.

\subsection{Provincial transparency and information provision}

Knowledge and information have been recognized as key elements of entrepreneurship (Shane, 2000; Shane \& Venkataraman, 2000). In emerging economies, local government officials 
differ greatly in their commitment and ability to create policies that are transparent and facilitate the information flow to support SMEs (Bertolini \& Giovannetti, 2006; Meyer \& Nguyen, 2005; Tran et al., 2009). Officials who appreciate the generation of new ideas and innovation have tried to make business information available to private businesses. This information includes government policies and plans and information about local, national, and international markets. The information channels include provincial Websites, publications, regular meetings with entrepreneurs, and public channels such as television stations and newspapers. While the number of channels and quantity of information may vary, the common principle in these provinces is to make policies transparent and consistent, and to make information as available as they can to promote more new firms and new business ideas (Tran et al., 2009; VNCI-VCCI, 2006).

In contrast, some provinces are less committed to improving policy transparency and information availability for SMEs. The officials often cite illegal activities committed by private firms to justify for their caution toward private SMEs. While reliable statistics on this phenomenon are not available, there have been a number of ghost firms (firms that only exist on paper) or cheating firms (e.g., those that cheated on taxes or conducted business outside of their registered areas) (Nguyen, 2005b; Tenev, Carlier, Chaudry, \& Nguyen, 2003). These officials are cautious with private business applications, especially those with unknown owners, or those with unfamiliar or strange business ideas (Tenev et al., 2003). Intense monitoring and checkup procedures may be applied in these cases. Therefore, policies may not be consistently applied to different cases and information may not be widely available since it may provoke unqualified private firms to take advantage of the information.

We argue that the province's perspective on information and knowledge sharing influences private firm performance. Provinces effectively reduce firm information costs by making information highly available. Informal or relationship costs involved in gaining support from officials are reduced when the policies are transparent and consistently applied (VNCI-VCCI, 2006). All directly increase private firm performance. Therefore, we hypothesize:

Hypothesis 2a. Provincial transparency and information availability positively influences private firm performance.

The transparency of policies and availability of information reduces business uncertainty, allowing firms to make informed choices in their strategies, resulting in a more effective use of resources. Information on export policies, foreign markets, and foreign partners is very important and positively impacts the export strategy (Denis \& Depelteau, 1985; Eriksson et al., 1997; Julien \& Ramangalahy, 2003). A lack of institutional knowledge is problematic as it would be difficult for firms to acquire an adequate understanding of the technical and commercial laws and norms that apply in a foreign market. Eriksson et al. cite examples of this knowledge, including how to import and export goods and services, tariffs, local taxes, general conditions in the markets, as well as related problems and prospects. Similarly, business knowledge (i.e., knowledge of customer needs and competition) is critical for SMEs to detect opportunities and mitigate uncertainty in foreign markets.

For exporters, information and knowledge of their home country's resources advantages (e.g., labor and natural resources) would help determine the firm's proper location and operations (Estrin et al., 2008). Export regulations and authorities' working styles are equally important. Transparent and available policies on related regulations help firms export effectively by reducing procedural time and costs. This is especially important for SMEs in emerging economies in which information is typically unavailable and fragmented, role models of successful internationalization strategies are scarce, and legal procedures are cumbersome and time-consuming (Neupert, Baughn, \& Dao, 2006; Tesfom \& Lutz, 2006).

Transparent and available policies can ease local market access by facilitating access to different customers and distribution channels, and by preventing local incumbents from using relationships with government officials to protect their markets (Estrin et al., 2008). In such contexts, SMEs may face better opportunities for growth by developing their local market position. The decision to do business internationally would be more carefully weighed against the alternative of penetrating domestic markets. Compared to those operating in non-transparent environments, SMEs in transparent environments are in better positions to select more effective export strategies. We expect provincial transparency to have a positive influence on the export strategy and the performance of the firm. Therefore, we hypothesize:

Hypothesis 2b. The more a province makes policies transparent and information available, the more positive impact the firm's export strategy will have on firm performance.

\section{Method}

\subsection{Data and sample}

Our research requires data at firm and provincial levels. At the firm level, our data come from a nation-wide survey of private firms in Vietnam, conducted by Vietnam Competitiveness Initiatives (VNCI) and Vietnam Chamber of Commerce and Industry (VCCI) in 2005-2006. A stratified sampling technique was applied in which firms in each province were randomly selected by legal form, economic segment (manufacturing, natural resource exploitation, service and commerce, and agriculture), and firm age. Of 31,186 surveys mailed out, 6379 responses were received, generating a response rate of over $20 \%$. Non-response bias tests confirmed that the sample adequately represents the population.

We have access to all the survey data, but only studied private manufacturing firms that were founded during the reform period (since 1986) and have been in operation for at least two years. The sample included firms with manufacturing revenue greater than $10 \%$ of their total revenue, have been in operation from two to 20 years, and have no state share in their ownership structure. This combination of criteria reduced the sample to 578 firms for subsequent analyses.

Provincial data came from published sources. Detailed descriptions are provided in the measurement section below.

\subsection{Measurement}

\subsubsection{Firm performance}

Firm performance was measured by pooled return on investment from 2004 to 2005. Respondents were asked to report the firm's profit/investment ratio on a scale from 1 to 3 with 1 being a big loss (a loss of 5\% or more), 3 is break-even, 6 is a profit from 5\% to $10 \%$, and eight is a profit of more than $20 \%$. Firm performance in 2004 significantly correlated with performance in 2005, providing some validation for our performance measure.

\subsubsection{Firm export strategy}

Following previous studies of private firms in transition economies (Luo et al., 2005; Lyles et al., 2004), export strategy is measured by the percentage of export sales compared to total sales in 2004. 


\subsubsection{Control variables at the firm level}

Based on the literature (e.g., Lyles et al., 2004), we controlled for firm size (measured by the number of employees), firm age, firm legal form, firm ownership of land use right certificate, firm proportion of service and construction of total sales, and the owner's experience with state organizations.

\subsubsection{Bias toward state-owned enterprises (SOEs bias)}

In Meyer and Nguyen (2005), the SOEs' influence was proxied by their output share in the total output of domestically-owned firms in the province. We argue that an inclusion of SOEs' share of the assets in total assets is necessary to better reflect SOEs' density in the province. While proportion of provincial revenue reflects SOEs' market penetration, the proportion of assets reflects SOEs' resources occupancy. SOEs can crowd out private SMEs by either penetrating the market, or consuming most of the resources, or both. Thus, in our study, SOE bias is measured by the proportion of SOEs' revenues and assets in the total revenues and assets of the business sectors in the province (i.e., foreign investment, SOEs, and private sector). The data we used came from the General Statistics Office of Vietnam (2005).

Since the share of SOEs' revenue and assets measured market penetration and resource consumption, it would not be sensible to average them together. In addition, these two measures interact to create a non-linear impact on private SMEs. Therefore, we multiplied these two indicators to create a measure of SOEs bias on a scale of zero to one. The higher the score, the more SOEs occupied the provincial economies, in term of input (i.e., asset) and output (i.e., revenue).

\subsubsection{Provincial transparency and information provision (hereafter referred to as provincial transparency)}

Provincial transparency is a measure of whether firms have access to proper planning and legal documents and business information necessary to run businesses, and whether those documents and information are equitably available. The VNCI research team's assessment of provinces' Webpages measured this variable. Provinces were assessed based on specific criteria, including whether provinces have a Webpage, whether a map of the province with industrial zones and major roads is available, and whether relevant information on provincial policies, incentive programs, land availability, industrial zones, and other business information is available, and number of accesses (for more details, please see the PCI 2006 summary report from the VNCI Webpage). These data created a range of scores from 0 to 18 , which we then standardized to a scale of 1-10 for data analysis. The measure was then validated with firms' perceptions of equity in accessing information from the VNCI survey. The correlation between this transparency and access to information measurement with firms' perceptions is positive and significant $(0.36, p<0.01)$. A recent study on e-government, also funded by VNCI (2006), suggested a strong linkage between provincial internet penetration levels and the level of a provincial government's commitment to transparency, openness, and information on a province's Website, further validating the choice of our Website score as a proxy of local government transparency and information provision. Control variables at the provincial level included the number of telephones per capita and freight transported (millions of tons) on provincial roads per kilometer (data are from 1995 to 2002).

\subsection{Analysis}

Analyses were performed using Raudenbush and Bryk's (2002) HLM. In our study, the level-one model portrayed relationships between firm (control) variables and export strategy with firm performance. These relationships can be described using estimated intercept and slope parameters. The parameters were then treated as dependent variables in the level-two analysis, where they were predicted using the provincial institution variables. First, we ran the complex model that included all variables. Then we simplified the model by taking out non-significant control variables at both levels. The results are similar, except for minor changes in the coefficients. We have only reported the simplified model's results.

\section{Results}

\subsection{Descriptive statistics}

The correlation matrix and descriptive statistics for both levelone and level-two variables are reported in Table 1 . The sample consists of 578 firms that had an average of 49 employees and five years in operation. The average proportion of exports to total sales is $5.6 \%$. The average return on investment (on a scale of $1-8$ ) is 4.13 , equivalent to a profit of $2.5-3.0 \%$. On average, SOEs accounted for $50 \%$ of total revenues and $55 \%$ of total assets in the provincial business sectors. These combined to create a measure of SOEs bias with an average value of 0.23 .

Firm performance significantly correlated to firm age, firm size, proportion of service and trading, and export revenue. Three provincial institutional variables correlated highly with the number of telephones per capita and freight transportation. None of the provincial level variables significantly correlated with firm performance.

Table 1

Correlations matrix.

\begin{tabular}{|c|c|c|c|c|c|c|c|c|c|c|c|c|c|}
\hline & Mean & S.D. & 1 & 2 & 3 & 4 & 5 & 6 & 7 & 8 & 9 & 10 & 11 \\
\hline 1. Owner experience & 0.33 & 0.47 & & & & & & & & & & & \\
\hline 2. Land certificate & 0.56 & 0.50 & 0.06 & & & & & & & & & & \\
\hline 3. Legal form & 2.17 & 1.10 & 0.15 & $-0.15^{\mathrm{a}}$ & & & & & & & & & \\
\hline 4. Firm age & 5.14 & 3.42 & -0.05 & $0.11^{\mathrm{a}}$ & $-0.20^{\mathrm{a}}$ & & & & & & & & \\
\hline 5. Firm size & 48.9 & 116.6 & 0.05 & -0.01 & $0.11^{\mathrm{a}}$ & 0.03 & & & & & & & \\
\hline 6. Service/construction revenue (\%) & 28.72 & 31.93 & 0.02 & 0.01 & -0.02 & -0.03 & -0.20 & & & & & & \\
\hline 7. Export strategy & 5.59 & 20.74 & -0.05 & -0.07 & $0.13^{\mathrm{a}}$ & 0.07 & 0.05 & 0.01 & & & & & \\
\hline 8. SOE bias & 0.23 & 0.12 & -0.08 & 0.03 & $-0.15^{a}$ & -0.01 & $-0.12^{\mathrm{a}}$ & 0.04 & -0.05 & & & & \\
\hline 9. Transparency & 5.99 & 2.57 & -0.02 & $-0.14^{\mathrm{a}}$ & $0.10^{\mathrm{b}}$ & 0.01 & 0.08 & 0.00 & $0.14^{\mathrm{a}}$ & $-0.14^{\mathrm{a}}$ & & & \\
\hline 10. Telephone/capita & 45.04 & 45.34 & 0.00 & $-0.23^{\mathrm{a}}$ & $0.20^{\mathrm{a}}$ & -0.04 & $0.12^{\mathrm{a}}$ & -0.02 & $0.17^{\mathrm{a}}$ & -0.08 & $0.54^{\mathrm{a}}$ & & \\
\hline 11. Freight transportation & 0.17 & 0.23 & -0.01 & -0.05 & 0.07 & -0.01 & -0.01 & 0.02 & 0.03 & 0.05 & $0.25^{\mathrm{a}}$ & $0.23^{\mathrm{a}}$ & \\
\hline 12. Performance & 4.13 & 1.16 & 0.01 & 0.01 & -0.05 & $0.11^{\mathrm{a}}$ & $0.27^{\mathrm{a}}$ & $0.11^{\mathrm{a}}$ & $0.09^{\mathrm{b}}$ & -0.03 & 0.04 & -0.01 & -0.03 \\
\hline
\end{tabular}

$N=578$.

a Correlation is significant at the 0.01 level (two-tailed).

b Correlation is significant at the 0.05 level (two-tailed). 
Table 2

Results of hierarchical linear modeling analysis-unconditional model.

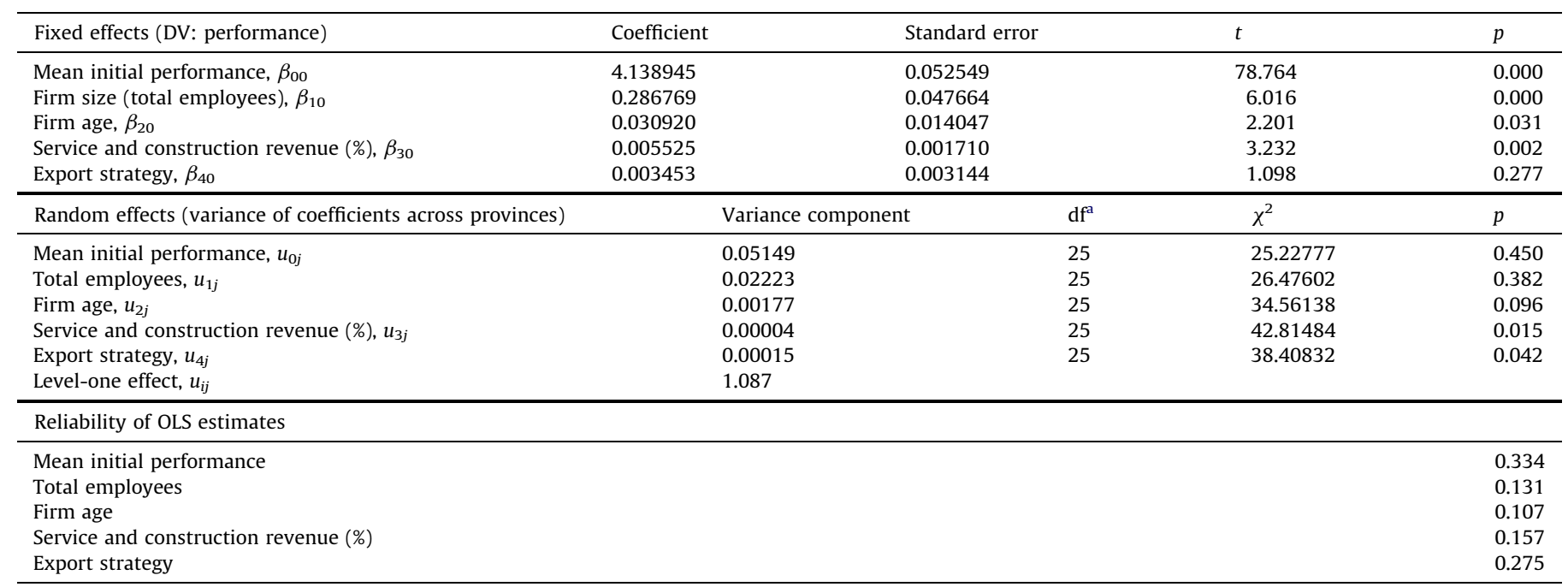

$N=578$.

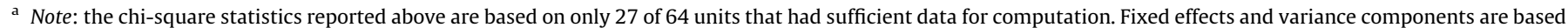
on all the data.

\subsection{A random-effects ANOVA model (null model)}

Our analysis began with fitting a one-way random-effects ANOVA model in order to determine the total variability amount in the outcome (ratio of profit/investment) within and between provinces. This model has no level-one predictors and we refer to it as the null model. The average firm performance mean, $\beta_{00}$, was estimated at 4.13. The pooled within province (level-one) variance, or $\sigma^{2}$, was 1.32 . Firm level variables explained some of this variance when we introduced the level-one model. The variance among the $J$ province means was 0.02 .

\subsection{A random-coefficient regression model (unconditional model)}

The next step in conducting HLM analysis is to estimate an unconditional model; that is, a model containing no level-two predictors. In the context of our analysis, this model provided the average initial performance (intercept) and the average coefficient of each level-one predictor (slope) on firm performance. It also provided an important baseline for subsequent analysis.

First, we included all control and firm level variables of interest in the model. Three variables (owner background, ownership of land certificate, and legal form) were not significant. To simplify the model, we dropped these non-significant variables from the level-one model. Then we re-ran the level-one model with four variables: firm age, total employment, percentage of direct export revenue, and percentage of service and construction. The analysis' results are presented in Table 2.

Compared to the null model, the estimated random effects variance at level-one has been reduced from 1.32 to 1.087 , after taking into account firm age, total employment (at the establishment time), firm proportion of service and construction of total sales, and export strategies. The variance proportion explained by this level-one model is $17.65 \%$.

The top portion of Table 2 presents the fixed effects results for the unconditional model, e.g., the estimated mean performance and slopes of the predictors. The significant $t$ ratios for each parameter suggest that each is necessary for describing the firm performance. Firm size had a positive relationship with firm performance $(t=6.016, p<0.001)$, indicating that the bigger the firm, the higher the return on investment. Similarly, firm age was positively related to firm performance $(t=2.201, p<0.05)$. The service and construction revenue percentage was also positively related to firm performance $(t=3.332, p<0.01)$. On the other hand, firm export strategy (direct export percentage) did not significantly relate to performance. However, the impact of export strategy may vary across provinces with different institutions.

The next section of Table 2 reports the variance components for the random effects. These parameters were central to investigating the nature of the deviation of level-one predictors' impacts on firm performance across provinces. The variance component of the initial mean performance (intercept) was not significant, suggesting that there might not be enough variance between provinces on initial performance. Of the four predictors, proportion of service and trading and export strategy had significant variance components. These data indicate that the export strategy's impact on firm performance does in fact vary across provinces.

The last section of Table 2 reports the estimated slope and intercept parameters' reliabilities. These reliability estimates represent the proportion of between group variance that is systematic (i.e., that can be modeled in the level-two equation using between-province variables). Raudenbush and Bryk (2002) suggested that whenever the reliability of a random level-one coefficient drops below 0.05 , that coefficient is a candidate for treatment either as fixed or non-randomly varying variable. In the model, all variables have acceptable levels of reliability.

The results taken together show that it is worthwhile to model export strategy's slopes as a function of our level-two variables. For exploratory purposes, we retained the intercept as a function of our level-two variables. Control variables were retained as fixed factors.

\subsection{The intercept- and slope-as-outcome model (conditional model)}

We then used the intercept- and slope-as-outcome model to test the influence of provincial variables (level-two) on the initial mean performance (intercept) and the relationship (i.e., regression coefficient) between export strategies and firm performance. Provincial institutional variables were used to model the intercept and slopes of export strategy estimated at level-one. Control 
Table 3

Result of hierarchical linear modeling analysis-conditional model.

\begin{tabular}{|c|c|c|c|c|}
\hline Fixed effects & Coefficient & Standard error & $t$ & $p$ \\
\hline \multicolumn{5}{|c|}{ Model for initial performance (DV: intercept of firm performance regression) } \\
\hline Base, $\beta_{00}$ & 3.939 & 0.1055 & 37.324 & 0.000 \\
\hline SOE bias, $\beta_{02}$ & -0.014304 & 0.0033 & -4.291 & 0.000 \\
\hline Transparency, $\beta_{03}$ & 0.021924 & 0.0099 & 2.201 & 0.031 \\
\hline Employment (base, $\beta_{10}$ ) & 0.2953 & 0.0481 & 6.143 & 0.000 \\
\hline Firm age (base, $\beta_{20}$ ) & 0.0352 & 0.0140 & 2.512 & 0.013 \\
\hline Service and construction revenue (\%) & 0.0054 & 0.0018 & 3.050 & 0.003 \\
\hline \multicolumn{5}{|c|}{ Export strategy (DV: coefficient of export strategy on firm performance) } \\
\hline Base, $\beta_{40}$ & 0.000444 & 0.00618 & 0.072 & 0.943 \\
\hline SOE bias, $\beta_{42}$ & 0.00074 & 0.00014 & 5.182 & 0.000 \\
\hline Transparency, $\beta_{43}$ & 0.000181 & 0.00050 & 0.363 & 0.717 \\
\hline Random effects & Variance component & $\mathrm{df}^{\mathrm{a}}$ & $\chi^{2}$ & $p$ \\
\hline Mean initial performance & 0.03543 & 24 & 27.55578 & 0.279 \\
\hline Export strategy & 0.00010 & 24 & 33.20298 & 0.100 \\
\hline Level-one effect, $u_{i j}$ & 1.16024 & & & \\
\hline
\end{tabular}

$N=578$.

${ }^{\text {a }}$ Note: the chi-square statistics reported above are based on only 27 of 64 units that had sufficient data for computation. Fixed effects and variance components are based on all the data.

variables at the provincial level did not significantly influence firm performance, nor did they affect the slope of export strategy. These control variables were then dropped to simplify the model. After dropping these variables, the results were similar to the original model, except for minor changes in coefficients. The results of this simplified model are presented in Table 3.

Results for initial performance (intercept) were reported in the top portion of Table 3. SOEs bias had a negative and significant relationship with firm performance. Specifically, firms performed better if they operate in provinces that have a lower density of SOEs. This result supported Hypothesis 1a. On the other hand, provincial transparency had a positive and significant association with firm performance, suggesting that firms enjoyed a higher performance in provinces that provided more and better information. Hypothesis 2a was supported.

Results for the slope (or coefficient) of export strategy was presented in the lower portion of Table 3. SOEs' bias had a positive and significant coefficient to the slope of export strategy, indicating that export strategy had a stronger association with firm performance in more pro-SOE provinces. Hypothesis $1 \mathrm{~b}$ was supported. Provincial transparency had a positive but nonsignificant coefficient on the slope. Hypothesis $2 \mathrm{~b}$ was not supported. Firm age and firm size remained as significant fixed factors of firm performance in this conditional model.

Table 4 reports the variance in initial performance (intercept) and slope of export strategy explained by the provincial variables. These estimates were computed by comparing the random effects variance components in the unconditional model (Table 2) to those obtained in the conditional model (Table 3 ). The variance explained statistic is the ratio of total parameter variance (i.e., the unconditional model), less residual parameter variance (i.e., the conditional model), over the total parameter variance. As Table 4 indicates, the provincial institutional variables explained $32 \%$ of the variance in initial performance and 33\% of the export strategy

Table 4

Variance explained in initial performance and slope of export strategy.

\begin{tabular}{lcc}
\hline Model & $\begin{array}{l}\text { Initial } \\
\text { performance }\end{array}$ & $\begin{array}{l}\text { Slope of direct } \\
\text { export revenue }\end{array}$ \\
\hline Unconditional & 0.05149 & 0.00015 \\
Conditional & 0.03543 & 0.00010 \\
Percent variance explained & $32 \%$ & $33 \%$ \\
\hline
\end{tabular}

slope. The variance component of export strategy became nonsignificant in this level-two model.

\section{Discussion}

Our results suggest that at the institutional level, different aspects of reform may have different impacts on a private firm's performance. At the firm level, export strategy did not appear to have a significant impact on firm performance. However, institutional factors moderated the export strategy's contribution to firm performance. Our study's results support the thesis that a firm's performance is a function of its strategy, its institutional environment, and these factor's interactions. Therefore, the effectiveness of a firm's strategy is constrained by the institutional environment it is operating in.

\subsection{Managerial relevance}

The results from our study indicate that SOE bias has a negative influence on firm performance while institutional transparency has a positive influence on firm performance. Private firms could use this knowledge by strategically choosing to establish their businesses in provinces in which there are high levels of transparency and low levels of SOE bias. While resources and geographic location of the localities have long been attractions for business, institutional factors should also be considered in making firm location decisions.

Our study also suggests that a simple export strategy may not necessarily help private firms in transition economies improve their performance. It appears that exporting becomes a viable strategy once the domestic market is too dominated by SOEs. Finally, our results suggest that managers should have a good information network as well as support from their local governments in order to improve their export performance.

\subsection{Limitations}

Our study's limitations need to be acknowledged in considering our findings and our study's implications. The cross-sectional design limits the validity of the implied causal links of the model at the firm level. The sample size, while it is relatively large in total $(N=578)$ for any study in emerging economies, is still considered small when averaged over 64 provinces. Our measures on 
provincial variables could be improved when data are more available in Vietnam.

\subsection{Contribution}

Our study contributes to the literature in several ways. First, our integrative, multi-level model allows us to combine different theoretical perspectives. This integration is necessary for examining factors at different levels of analysis (Deephouse, 1999; Hofmann, 1997). The direct impacts of a firm's strategy and institutional factors on firm performance are well specified by the resource-based view (RBV), generic strategies, and institutional theory, respectively. The idea that institutional factors moderate the relationships between firm strategies and performance fits well with traditional contingency theory (Burns \& Stalker, 1961; Woodward, 1958). However, these perspectives are often presented as separate or even conflicting approaches to organization strategies. We have provided a more comprehensive view of how different factors influence firm performance by combining these perspectives in a model. We show that the perspectives are neither necessarily mutually exclusive nor conflicting in nature; they can operate jointly and simultaneously.

While recognizing that the institutional environments in emerging economies have a profound influence on firm strategies and performance (e.g., Peng, 2002), previous research provided little explanation on influence mechanisms and empirical evidence. Our study is one of the rare attempts to explicitly model institutions as independent and moderating variables of firm performance. We not only recognize the importance of institutions, but more importantly, we identify the driving logic and explain the underlying mechanisms of these institutional influences.

Our research provides some support for the argument that institution-based view could be the "third leg" in international business research (Peng et al., 2008, p. 923); the others are resource- and industry-based views. Previous research on firm export performance often assumed institutions as "background" (Gao et al., 2010). This is a serious shortcoming when examining a firm's export performance in an emerging economy. In these economies, institutions are more salient because the rules are being continually and fundamentally changed. Omitting homecountry institutional environment in examining export performance would limit our understanding of factors influencing export performance. Our research has demonstrated that institutional factors can both directly influence firm performance and moderate the relationship of a firm's export strategy on performance.

Having recognized the relevance of the institutional perspective, we believe that the institutional perspective should not be simply viewed as just another, albeit complementary, perspective in international business research. Current research tends to view institutional factors separately from firm capability and industry factors and tests if institutions have effects on export performance that are "above and beyond" impacts of other factors (e.g., Gao et al., 2010). While this approach is of certain value, we believe the field would benefit from an integration of the institutional perspective with other perspectives and specify how institutional factors interact with factors to influence firm export performance.

Scholars who employ the institutional perspective in international business research often have to employ different levels of analysis, examining entrepreneurs, firms, and local and national institutions (Szyliowicz \& Galvin, 2010). These levels are interrelated and connected. Identifying the interrelationships and connections between factors at different levels is a way to specify the underlying mechanisms of institutional influences on firm export performance. We studied, at provincial and firm levels, factors contributing to the treatment of different levels in international business research.

Methodologically, organizational scholars have been struggling with combining different levels of analysis in their empirical research (Hofmann, 1997). Organizations, by nature, are hierarchically ordered systems. The challenge has been how to examine the influence of variables at one hierarchical level on variables at another hierarchical level without (deceptively) converting all data into one level. Our model specifies the relationships between variables residing at different hierarchical levels. The analytical method allows us to investigate these relationships while maintaining the appropriate level of analysis. We believe this type of methodology would benefit organizational research in the future.

We provide further insight into the dynamics of firm strategies in transitional economies. Timing is clearly a critical success factor for any strategy. With rapid changes in institutions, any successful strategy could be temporary. Thus, for private firm managers, perhaps the most important capability they need to develop is the ability to adapt to institutional changes, or "strategic flexibility" (Uhlenbruck, Meyer, \& Hitt, 2003). As the reform progresses (i.e., less bias against SOEs), simple exporting strategies may lose their effectiveness. Instead, other strategies that require more involvement in foreign markets may be more beneficial for SMEs.

\subsection{Future research implications}

While the interplay between institutional factors and organizations was not examined in this paper, we believe this could be a fruitful endeavor for future research. To date, research in international business has focused largely on examining the influences of institutional factors upon organizations, leaving the continual interplay between organizations and their environment understudied (Szyliowicz \& Galvin, 2010). In our sample, it is reasonable to expect that the more firms export, the stronger they push their local institutions for better transparency and equal treatment. How do these firms enact their environment? How do firms and their institutions interplay and co-evolve? Addressing these questions would advance our understanding of the institutional influence in internationalization process.

\section{Conclusion}

The transformation from state control to a market economy has a significant impact on private firm performance in many emerging economies. Private sector development has played a major role in facilitating or driving this transformation. This co-evolution has set the pace of reform in these countries. In such a context, developing a better understanding of how institutional factors impact firm strategies and performance is a research imperative. We set out in this study to advance the literature on SMEs' strategy in emerging economies by examining factors affecting private firm performance. We have demonstrated that government reforms not only impact firm performance, but also push firms toward developing strategies that are more effective in competing with foreign rivalries. For private firms in Vietnam, this insight is of particular relevance as the country has actively engaged in the globalization process.

\section{Acknowledgements}

The first author would like to thank the University of Macau for financial support for this project (Grant RG039/06-07S/TNV/FBA). The authors would also like to thank Rilla Esbjornson for her valuable help with editing multiple drafts of this manuscript. 


\section{References}

Bertolini, P., \& Giovannetti, E. (2006). Industrial districts and internationalization: The case of the agri-food industry in Modena, Italy. Entrepreneurship \& Regional Development, 18(4): 279-304.

Buckley, P. J., Cregg, L. J., Cross, A. R., Liu, X., Voss, H., \& Zeng, P. (2007). The determinants of Chinese outward foreign direct investment. Journal of International Business Studies, 38(4): 499-518.

Burns, T., \& Stalker, G. M. (1961). The management of innovation. London: Tavistock Publications.

Deephouse, D. L. (1999). To be different, or to be the same? It's a question (and theory) of strategic balance. Strategic Management Journal, 20(2): 147-166.

Denis, J., \& Depelteau, D. (1985). Market knowledge, diversification and export expansion. Journal of International Business Studies, 16(3): 77-89.

Eriksson, K., Johanson, J., Majkgard, A., \& Sharma, D. D. (1997). Experiential knowledge and cost in the internationalization process. Journal of International Business Studies, 28(2): 337-359.

Estrin, S., Meyer, K. E., Wright, M., \& Foliano, F. (2008). Export propensity and intensity of subsidiaries in emerging economies. International Business Review, 17(5): 574-586.

Gao, G. Y., Murray, J. Y., Kotabe, M., \& Lu, J. (2010). A “strategy tripod" perspective on export behaviors: Evidence from domestic and foreign firms based in an emerging economy. Journal of International Business Studies, 41(3): 377-396.

General Statistics Office of Vietnam. (2005). Retrieved from http://www.gso.gov.vn

Hofmann, D. A. (1997). An overview of the logic and rationale of hierarchical linear models. Journal of Management, 23(6): 723-744.

Hoskisson, R. E., Eden, L., Lau, C. M., \& Wright, M. (2000). Strategy in emerging economies. Academy of Management Journal, 43(3): 249-267.

Julien, P., \& Ramangalahy, C. (2003). Competitive strategy and performance of exporting SMEs: An empirical investigation of the impact of their export information search and competencies. Entrepreneurship Theory and Practice, 27(3): 227-245.

Le, N. T. B., Venkatesh, S., \& Nguyen, T. V. (2006). Getting bank financing: A study of Vietnamese private firms. Asia Pacific Journal of Management, 23(2): 209-227.

Lu, J. W., \& Beamish, P. W. (2001). The internationalization and performance of SMEs. Strategic Management Journal, 22(6-7): 565-586.

Luo, X., Zhou, L., \& Liu, S. S. (2005). Entrepreneurial firms in the context of China's transition economy: An integrative framework and empirical examination. Journal of Business Research, 58(3): 277-284.

Luo, Y., \& Tung, R. L. (2007). International expansion of emerging market enterprises: A springboard perspective. Journal of International Business Studies, 38: 481-498.

Lyles, M. A., Saxton, T., \& Watson, K. (2004). Venture survival in a transition economy. Journal of Business Venturing, 30(3): 351-375.

Meyer, K., \& Nguyen, H. V. (2005). Foreign investment strategies and sub-national institutions in emerging market: Evidence from Vietnam. Journal of Management Studies, 42(1): 63-93.

Meyer, M. W., \& Boisot, M. (2008). Which way through the open door? Reflections on the internationalization of Chinese firms. Management and Organization Review, 4(3): 349-365.

Neupert, K. E., Baughn, C. C., \& Dao, T. T. L. (2006). SME exporting challenges in transitional and developed economies. Journal of Small Business and Enterprise Development, 13(4): 535-545.

Nguyen, V. T. (2005a). Learning to trust: A study of interfirm trust dynamics in Vietnam. Journal of World Business, 40(2): 203-221.

Nguyen, V. T. (2005b). Are state-owned enterprises crowding out the private sector? Evidence from Provincial Competitiveness Index. Policy Research Report, Hanoi, Vietnam: Vietnam Competitiveness Initiatives (VNCI).

Nguyen, V. T., Le, N. T. B., \& Freeman, N. J. (2006). Trust and uncertainty: A study of bank lending to private SMEs in Vietnam. Asia Pacific Business Review, 12(4): 547-568.

North, D. (1990). Institutions, institutional change and economic performance. Cambridge, NY: Cambridge University Press.
Oviatt, B. M., \& McDougall, P. P. (1994). Toward a theory of international new ventures Journal of International Business Studies, 25(1): 45-64.

Peng, M. W. (2001). How entrepreneurs create wealth in transition economies. Academy of Management Executive, 15(1): 95-108.

Peng, M. W. (2002). Toward an institutional-based view of business strategy. Asia Pacific Journal of Management, 19(2-3): 251-267.

Peng, M. W. (2003). Institutional transitions and strategic choices. Academy of Management Review, 28(2): 275-296.

Peng, M. W., Wang, D. Y. L., \& Jiang, Y. (2008). An institution-based view of international business strategy: A focus on emerging economies. Journal of International Business Studies, 39(5): 920-936.

Ramasamy, B., Yeung, M., \& Laforet, S. (in press). China's outward foreign direct investment: Location choice and firm ownership. Journal of World Business, Retrieved from http://dx.doi.org/10.1016/j.jwb.2010.10.016.

Ramirez, C. D., \& Tan, L. H. (2004). Singapore Inc. versus the private sector: Are government-linked companies different? IMF Staff Papers, 51(3): 510-528.

Raudenbush, S. W., \& Bryk, A. S. (2002). Hierarchical linear models: Application and data analysis methods. Thousand Oaks, CA: Sage.

Shane, S. (2000). Prior knowledge and the discovery of entrepreneurial opportunities. Organization Science, 11(4): 448-469.

Shane, S., \& Venkataraman, S. (2000). The promise of entrepreneurship as a field of research. Academy of Management Review, 25(1): 217-226.

Smallbone, D., \& Welter, F. (2001). The distinctiveness of entrepreneurship in transition economies. Small Business Economics, 16(4): 249-262.

Szyliowicz, D., \& Galvin, T. (2010). Applying broader strokes: Extending institutional perspectives and agendas for international entrepreneurship research. International Business Review, 19: 317-332.

Tenev, S., Carlier, A., Chaudry, O., \& Nguyen, Q. T. (2003). Informality and the playing field in Vietnam's business sector. Washington, D.C. IFC, World Bank and MPDF.

Tesfom, G., \& Lutz, C. (2006). A classification of export marketing problems of small and medium sized manufacturing firms in developing countries. International Journal of Emerging Markets, 1(3): 262-281.

Tran, T. B., Grafton, R. Q., \& Kompas, T. (2009). Institutions matter: The case of Vietnam. The Journal of Socio-Economics, 38(1): 1-12.

Uhlenbruck, K., Meyer, K. E., \& Hitt, M. A. (2003). Organizational transformation in transition economies: Resource-based and organizational learning perspectives Journal of Management Studies, 40(2): 257-283.

VNCI. (2006). E-government and business competitiveness: A policy review. Hanoi, Vietnam: Vietnam Competitiveness Initiative.

VNCI-VCCI. (2005). The Provincial Competitiveness Index on the business environment in Vietnam: Summary report. Hanoi, Vietnam: Vietnam Competitiveness Initiative.

VNCI-VCCI. (2006). The Provincial Competitiveness Index on the business environment in Vietnam: Summary report. Hanoi, Vietnam: Vietnam Competitiveness Initiative.

Wengel, J., \& Rodriguez, E. (2006). SME export performance in Indonesia after the crisis. Small Business Economics, 26: 25-37.

Witt, M. A., \& Lewin, A. Y.(2007). Outward foreign direct investment as escape response to home country institutional constraints. Journal of International Business Studies, 38(4): 579-594.

Woodward, J. (1958). Management and technology. London: Her Majesty's Stationary Office.

Wright, M., Filatotchev, I., Hoskisson, R. E., \& Peng, M. W. (2005). Strategy research in emerging economies: Challenging the conventional wisdom. Journal of Management Studies, 42(1): 1-33.

Yamakawa, Y., Peng, M. W., \& Deeds, D. L. (2008). What drives new ventures to internationalize from emerging to developed economies? Entrepreneurship: Theory E Practice, 32(1): 59-82.

Zhu, H., Hitt, M., \& Tihanyi, L. (2007). The internationalization of SMEs in emerging economies: Institutional embeddedness and absorptive capacities. Journal of Small Business Strategy, 17(2): 1-26. 